\title{
L-ARGININE SUPPLEMENTATION IMPROVES POST-EXERCISE HYPOTENSION IN ELDERLY WOMEN
}

\author{
SUPLEMENTAÇÃO DE L-ARGININA POTENCIALIZA A HIPOTENSÃOPÓS-EXERCÍCIO EM MULHERESIDOSAS \\ LA SUPLEMENTACIÓN DE L-ARGININA POTENCIALIZA LA HIPOTENSIÓN POSTEJERCICIO EN MUJERES \\ DELATERCERAEDAD
}

Juliano Casonatto ${ }^{1}$

(Physical Education Professional)

Daniele Mantovani Zago'

(Physical Education Professional)

Daniel Massaharu Enokida'

(Nutritionist)

Kamila Grandolfi'

(Physical Education Professional)

Andreo Fernando Aguiar ${ }^{2}$

(Sport Professional)

1. Universidade Norte do Paraná (UNOPAR), Physiology and Physical Activity Research and Study Group (GEPEFAF), Health and Biological Sciences Center (CCBS), Londrina, PR, Brazil.

2. Universidade Norte do Paraná (UNOPAR), Centro de Ciências Biológicas e da Saúde (CCBS), Londrina, PR, Brazil.

\section{Correspondence:}

Juliano Casonatto

Rua Vereador Manoel de Oliveira Branco, 91, Vila Rica. Londrina, PR, Brazil. 86025-170. juliano2608@hotmail.com.br

\begin{abstract}
Introduction: L-Arginine supplementation increases plasma levels of nitric oxide (NO) metabolites, an important mediator of peripheral dilatation. Therefore, L-Arginine supplementation can improve the duration and magnitude of post-exercise hypotension. Objectives: This study investigated the effects of L-Arginine supplementation on post-exercise hypotension, femoral artery area and heart rate variability in elderly women. Methods: Twenty prehypertensive and hypertensive adult female participants were divided (in a random and balanced manner) into two groups (placebo and L-arginine). The participants ingested eight grams of inert substance (placebo group) or eight grams of L-Arginine (L-arginine group), dissolved in water, 90 min prior to the experimental session. The experimental session consisted of an isokinetic maximal strength test. Blood pressure was measured using an oscillometric device (Omron MX3 Plus, Bannockburn, US) every 10 minutes for 60 minutes after the experimental session. Femoral artery area (ultrasound) and heart rate variability were also analyzed. Data underwent repeated measures (ANOVA) analysis and respective assumptions. Results: L-Arginine supplementation associated with exercise produced a significant decrease in systolic blood pressure [placebo vs L-Arginine] ( $p<0.05)$ at the "half-life" time point (90 minutes after supplementation) $(141 \pm 12$ vs $130 \pm 11$

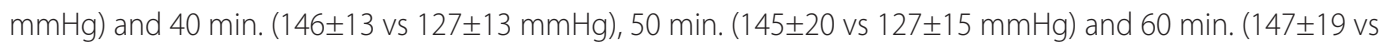
$129 \pm 14 \mathrm{mmHg}$ ) post-exercise. No significant differences were identified in femoral artery area and heart rate variability. Conclusion: Acute L-Arginine supplementation can increase post-exercise hypotension effects in elderly women. Additionally, acute L-Arginine supplementation is not related to either femoral artery area or heart rate variability responses. Level of evidence l; Randomized clinical trial.
\end{abstract}

Keywords: Arterial pressure; Vasodilation; Arginine.

\section{RESUMO}

Introdução: A suplementação de L-arginina aumenta os níveis plasmáticos dos metabólitos de óxido nítrico, um importante mediador da dilatação periférica. Dessa forma, épossivel que a suplementação de L-arginina maximize a duração e a magnitude dos efeitos hipotensores pós-exercício. Objetivos: O presente estudo investigou os efeitos da suplementação de L-arginina na hipotensão pós-exercício, área da artéria femoral evariabilidade da frequência cardíaca em mulheres idosas. Métodos: Vinte participantes, adultas, pré-hipertensas e hipertensas foram divididas (de modo aleatório e equilibrado)em dois grupos (placebo e L-arginina). As participantes ingeriram oito gramas de substância inerte (grupo placebo) ou oito gramas de L-arginina (grupo L-arginina), dissolvido em água, 90 min antes da realização da sessão experimental. A sessão experimental consistia em um teste de força isocinética máxima. A pressão arterial foi aferida utilizando um dispositivo oscilométrico (Omron MX3 Plus, Bannockburn, EUA) a cada 10 minutos, durante 60 minutos, após o término da sessão experimental. Foram analisadas ainda a variabilidade da frequência cardíaca e a área da artéria femoral (ultrassom). Os dados foram submetidos à análise de variância para medidas repetidas (ANOVA) e seus respectivos pressupostos. Resultados: A suplementação de L-arginina associada ao exercício promoveu redução significativa da pressão arterial sistólica [placebo vs. L-arginina] $(p<0,05)$ no intervalo de "meia-vida" (90 minutos após a suplementação) $(141 \pm 12 \mathrm{vs.} 130 \pm 11 \mathrm{mmHg})$ e aos 40

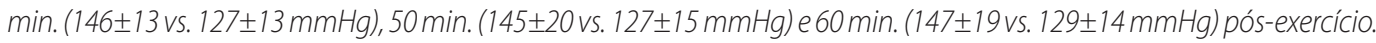
Não foram identificadas diferenças significativas na área da artéria femoral e na variabilidade da frequência cardiaca. Conclusão: A suplementação aguda de L-arginina pode potencializar os efeitos hipotensores pós-exercício em mulheres idosas. Além disso, a suplementação de L-arginina aguda não está associada às respostas de variabilidade da frequência cardíaca ou da área da artéria femoral. Nível de evidência l; Ensaio clínico randomizado.

Descritores: Pressão arterial; Vasodilatação; Arginina.

\section{RESUMEN}

Introducción: La suplementación de L-arginina aumenta los niveles plasmáticos de los metabolitos de óxido nítrico, un importante mediador de la dilatación periférica. Deesa forma, es posible que la suplementación de L-arginina maximice la duración y la magnitud de los efectos hipotensores post ejercicio. Objetivos: El presente estudio investigó los efectos de la suplementación de L-arginina en la hipotensión post ejercicio, área de la arteria femoral y variabilidad de la frecuencia cardíaca en mujeres de la tercera edad. Métodos: Veinte participantes, adultas, pre hipertensas e hipertensas fueron divididas (de modo aleatorio y equilibrado) en dos grupos (placebo y L-arginina). Las participantes ingirieron ocho gramos 
de sustancia inerte (grupo placebo) u ocho gramos de L-arginina (grupo L-arginina), disuelta en agua, 90 minutos antes de la realización de la sesión experimental. La sesión experimental consistía en un test de fuerza isocinética máxima. La presión arterial fue medida utilizando un dispositivo oscilométrico (Omron MX3 Plus, Bannockburn, EE.UU.) a cada 10 minutos, durante 60 minutos, después del término de la sesión experimental. Fueron analizadas además la variabilidad de la frecuencia cardíaca y el área de la arteria femoral (ultrasonido). Los datos fueron sometidos a análisis de variancia para medidas repetidas (ANOVA) y sus respectivas premisas. Resultados: La suplementación de L-arginina asociada al ejercicio promovió reducción significativa de la presión arterial sistólica [placebo vs. L-arginina] $(p<0,05)$ en el intervalo de

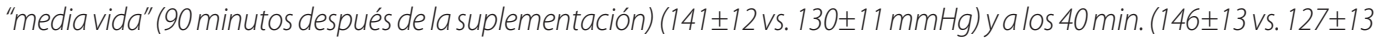

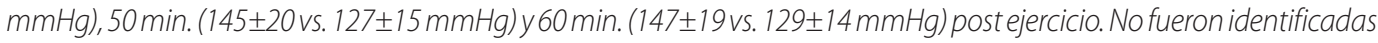
diferencias significativas en el área de la arteria femoral ni en la variabilidad de la frecuencia cardíaca. Conclusión: La suplementación aguda de L-arginina puede potencializar los efectos hipotensores post ejercicio en mujeres de la tercera edad. Además, la suplementación de L-arginina aguda no está asociada a las respuestas de variabilidad de la frecuencia cardíaca o del área de la arteria femoral. Nivel de evidencia l; Ensayo clínico aleatorizado.

Descriptores: Presión arterial; Vasodilatación; Arginina.

\section{INTRODUCTION}

The social conditions and technological advances evidenced in the last century allowed a significant improvement in the health conditions of the population. Consequently, there has been a significant increase in life expectancy and an increase in the elderly population. In this scenario, infect-contagious diseases, which were responsible for high mortality rates, are no longer prevalent ${ }^{1}$. On the other hand, there is a significant prevalence/incidence increase of chronic-degenerative diseases due to modern lifestyle characteristic. Among chronic-degenerative diseases, systemic arterial hypertension and, consequently, cardiovascular diseases ${ }^{2}$.

Physical activity practice is an important non-pharmacological resource for maintaining blood pressure control. Several studies have demonstrated that regular exercise promotes chronic blood pressure (BP) reduction, through aerobic ${ }^{3}$ or resistance ${ }^{3}$ exercise. In addition, there is still an acute reduction phenomenon called post-exercise hypotension (PEH), identified in both normotensive ${ }^{4}$ and hypertensive $^{5}$ individuals.

Different regulatory mechanisms can be related to BP changes. In general, changes in cardiac contractility, microvessel density, arterial and venous blood volume, heart thickness and morphology can modulate BP. Thus, the autonomic nervous system also plays an important role in cardiovascular control, acting on heart rate, peripheral vascular resistance and consequently cardiac output and $\mathrm{BP}^{6}$.

The nitric oxide (NO) synthesis is another important process that must be considered in relation to BP. NO plays an important role in increasing blood flow, vasodilation, and blood perfusion ${ }^{7}$. NO can be produced in the mammalian organism or by the endogenous substrates such as L-Arginine (ARG) and L-Citrulline. Studies have shown that during the aging process there is a decrease in NO production and ARG (essential amino acid) ${ }^{8}$. This reduction is intrinsically related to physical exercise intolerance and cardiovascular risk factors ${ }^{9}$. Considering the importance of NO as a vasodilator, several pharmacological and nutritional therapies have emerged recently ${ }^{10}$.

Since ARG is the main endogenous substrate related to NO synthesis ${ }^{11}$, the ARG supplementation may play an important vasodilatory role, maximizing the already known post-exercise hypotensive effect, becoming another important tool for the treatment and prevention of hypertension. In this sense, the objective of the present study was to verify the impact of a single aerobic physical exercise session associated with ARG supplementation on BP, femoral artery area and heart rate variability (HRV) in elderly women.

\section{METHODS \\ Participants}

After the sample size calculation (see statistical analysis), 20 physically active elderly women (65-80 years old), who voluntarily participated in extension projects (general physical activities [functional exercises and stretching] offered to the community), were invited to compose the present investigation. The inclusion criteria were: (1) nonsmoker, (2) health musculoskeletal condition, (3) have not to use drugs that potentiate or block muscle action, (4) have not to use medicines that increase blood flow, (5) have no surgeries at least six months, (6) have not used ergogenic supplements for at least six months, (7) have no disease or cardiac complication in the last three years, and (8) medical approval for physical exercise practice. All participants were previously informed about the research objectives and procedures. They signed a free and informed consent form approved by the Research Ethics Committee (protocol no. 28443714.0.0000.0108). All procedures were carried out in accordance with Helsinki Declare (1964).

\section{Experimental Design}

The present study employed a randomized, double-blind experimental design with placebo group. Initially, all subjects were submitted to a quadriceps muscle isokinetic strength test familiarization. All participants received instructions related to exercise technique and instruments. This procedure was adopted to avoid potential learning effects and guarantee data reliability. Participants were divided randomly (using a random number table - https://www.random.org/) into two groups ( $\mathrm{N}=10$ per group): Placebo (PLA) and ARG (ARG). The participants were submitted to femoral artery doppler ultrasonography (performed by a specialized physician), into three moments: before ARG supplementation (moment 10 minutes [min].), After ARG supplementation (80 min.), and immediately after performing the isokinetic force test of the quadriceps muscle. Initially, participants were instructed to remain at rest for $30 \mathrm{~min}$, they were supplemented with ARG or placebo (8g in a single dose) and kept seated at rest for $80 \mathrm{~min}$. After this, the participants were submitted to ultrasound examination and isokinetic force test. HRV was continuously monitored. BP was monitored every $10 \mathrm{~min}$ intervals before (10, 20 and $30 \mathrm{~min})$ and after (40, 50, 60, 70, $80,90,100,110,120,130,140,150,160,170,180$ min.) supplementation.

\section{Familiarization Protocol}

To avoid potential learning effects and to ensure the reliability, all participants were submitted to a familiarization session to receive technique instructions related to isokinetic force test. Two familiarization 
training was carried out separated by at least 48 hours. This design was used to minimize the previous fatigue effects on strength tests and to guarantee maximum effort in each test. Each test was run three times during the familiarization phase. A 10 min recovery period was allowed between trials. During all tests, the subjects were continuously monitored and verbally encouraged.

\section{Anthropometry}

Anthropometric data were collected before the experimental session. The body mass was evaluated with an electronic scale (Plenna Acqua - São Paulo - Brazil). The portable wooden stadiometer was used to stature measures.

\section{Arginine supplementation}

Subjects were supplemented with ARG (Sigma Aldrich ${ }^{\circledR}$ ) or placebo (inert substance), in the same format. ARG was administered after 30 min ( $8 \mathrm{~g}$ - single dose) by the solution containing $300 \mathrm{ml}$ of $\mathrm{H}_{2} \mathrm{O}$. The tests were started at 90 min after supplementation (during half-life), considering ARG pharmacokinetic properties.

\section{Blood flow measurement}

All participants were submitted to a Doppler ultrasonography (System FiVe; GE Medical Systems), performed by a specialized physician. Longitudinal femoral artery images were obtained by a linear matrix (10-MHz) pulse doppler ultrasound probe.

\section{Isokinetic Strength}

After 80 min of supplementation, all participants underwent to an isokinetic evaluation (knee extensor and flexor muscles) of the dominant limb by the isokinetic dynamometer (Biodex Medical Systems - 3 Isokinetic Dynamometer, Long Island, NY). The participants were positioned on the equipment according to the manufacturer recommendations. The subjects were instructed to perform three sets (10 repetitions; 60\% $[1.05$ rad.s-1]), applying recovery time (1 min) between the series. The movement angle was set at $90^{\circ}$. The test was performed after specific warming (eight repetitions $-60 \%$, ) in which participants were instructed to do not perform the maximum effort. The dynamometer axis rotation was aligned to the femoral epicondyle, and the resistance load was allocated two centimeters above the internal malleolus. Possible errors induced by gravity were corrected based on the lower limb weight at $0 \%$ s and calculated by the equipment software. The subjects were continuously monitored and verbally encouraged by the evaluators. It was not allowed visual feedback.

\section{Blood Pressure Measures}

Resting BP was measured (every $10 \mathrm{~min}$ ) by a pre-validated automated monitor (Omron MX3 Plus, Bannockburn, USA) ${ }^{12}$. The subjects adopted the sitting position and the measurement was performed in the left arm, following the American Heart Association ${ }^{13}$ recommendations.

\section{Heart rate variability measurements}

HRV was monitored throughout the experimental session with a previously validated heart rate monitor (Polar - RS800CX, Kempele, Finland) ${ }^{14}$. The $R-R$ interval ranges recorded on the equipment were transferred to a computer using Polar Precision Performance software (release 3.00, Kempele, Finland). The Fourier transform was used to quantify the low (LF) and high frequency (HR) bands, according to the Task Force of the European Society of Cardiology and the North American Society of Electrophysiology ${ }^{15}$ recommendations. The time domain analysis was obtained by the RMSSD indices (square root of the mean of successive squared differences between adjacent R-Rs) and pNN50 (percentage of adjacent normal RR intervals with duration difference greater than $50 \mathrm{~ms}$ ). The time and frequency domain analysis were performed every 10 minutes, by the
Kubios HRV software. The "pre", "half-life" and "post" values were obtained by the mean of the moments, [10 and 20 min.]; [30, 40, 50, 60, 70, 80, 90, $100,110$ and $120 \mathrm{~min}] ;.[130,140,150,160,170$ and $180 \mathrm{~min}]$, respectively.

\section{Food Control}

Participants were instructed to maintain their usual daily activities and diet as well as to refrain from any strenuous activity and to avoid the rich nitrite/nitrate foods for three days before each session. A list describing foods that should be avoided was distributed to simplify their dietary choices. This list was developed based on nitrite/nitrate food estimates, as proposed by Griesenbeck ${ }^{16}$. Participants were also instructed to report any adverse events. Participants did not report adverse events.

\section{Statistical treatment}

Assuming a standard deviation of $5 \mathrm{mmHg}^{17}$ for systolic BP, an alpha of $5 \%$, and $80 \%$ of statistical power to detect a minimum difference of $7 \mathrm{mmHg}^{17}, 7$ participants were required in each group.

Independent Student's t-test was applied for baseline comparisons. Mauchly's test was applied to identify the data sphericity. In case of sphericity breach, the Greenhouse-Geisser correction was applied. Afterward, the data were submitted to variance analysis for repeated measures. LSD post-hoc test was used for multiple comparisons. The $P$ value $<0.05$ was adopted as statistically significant. Values are presented as mean and standard error. The data were analyzed with SPSS version 17.

\section{RESULTS}

The general characteristics (age, body mass, height, body mass index, heart rate, systolic/diastolic BP and femoral artery area) are presented in Table 1. There were no baseline significant differences $(P>0.05)$ between PLA and ARG.

The systolic BP values were significantly different at the "half-life" [90 min after supplementation] (141 \pm 12 vs $130 \pm 11 \mathrm{mmHg})$ and at 40 min. (146 \pm 13 vs. $127 \pm 13 \mathrm{mmHg}), 50 \mathrm{~min} .(145 \pm 20$ vs $127 \pm 15 \mathrm{mmHg})$ and $60 \mathrm{~min}$. (147 \pm 19 vs $129 \pm 14 \mathrm{mmHg}$ ) post-exercise (PLA vs ARG, respectively). Systolic BP remained higher at 10, 20, 30, and 40 min postexercise for PLA and at 10 and 20 min for ARG compared to rest. There were no diastolic BP differences (Figure 1).

Figure 2 presents femoral artery area results for "pre", "half-life" (90 min after supplementation) and "post". No statistically significant differences were identified.

Figures 3 and 4 present the time (figure 3) and frequency (Figure 4) HRV domains indicators. No statistically significant differences were identified.

\section{DISCUSSION}

To the best of our knowledge, this is the first randomized, double-blind, placebo-controlled study that examined the acute effects of oral ARG supplementation on post-exercise pressure and autonomic responses. It is worth mentioning that $\mathrm{PEH}$ is considered an important physiological phenomenon ${ }^{18}$, and may play a greater role in hypertension

Table 1. General characteristics of the sample.

\begin{tabular}{c|c|c|c}
\hline & ARG $(\mathbf{N}=10)$ & PLA $(\mathbf{N}=10)$ & P \\
\hline Age (years) & $70,6 \pm 2,2$ & $72,5 \pm 1,6$ & 0,709 \\
\hline Body mass $(\mathrm{kg})$ & $62,9 \pm 3,3$ & $60,4 \pm 2,1$ & 0,538 \\
\hline Height $(\mathrm{cm})$ & $153,2 \pm 2,3$ & $152,2 \pm 1,1$ & 0,699 \\
\hline BMI $\left(\mathrm{kg} \cdot \mathrm{m}^{2}\right)$ & $27,1 \pm 1,0$ & $26,1 \pm 0,7$ & 0,620 \\
\hline HR $(\mathrm{bpm})$ & $76,5 \pm 3,5$ & $70,3 \pm 2,8$ & 0,287 \\
\hline Systolic BP $(\mathrm{mmHg})$ & $121,5 \pm 6,0$ & $124,3 \pm 5,5$ & 0,123 \\
\hline Diastolic BP $(\mathrm{mmHg})$ & $73,8,1 \pm 1,7$ & $75,8 \pm 2,9$ & 0,793 \\
\hline Femoral artery area $\left(\mathrm{cm}^{2}\right)$ & $0,45 \pm 0,03$ & $0,41 \pm 0,02$ & 0,327 \\
\hline ARG= L-Arginine Group; PLA= Placebo Group; BMI= Body mass index; HR= Heart rate; BP= Blood pressure.
\end{tabular}




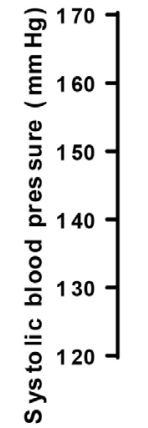
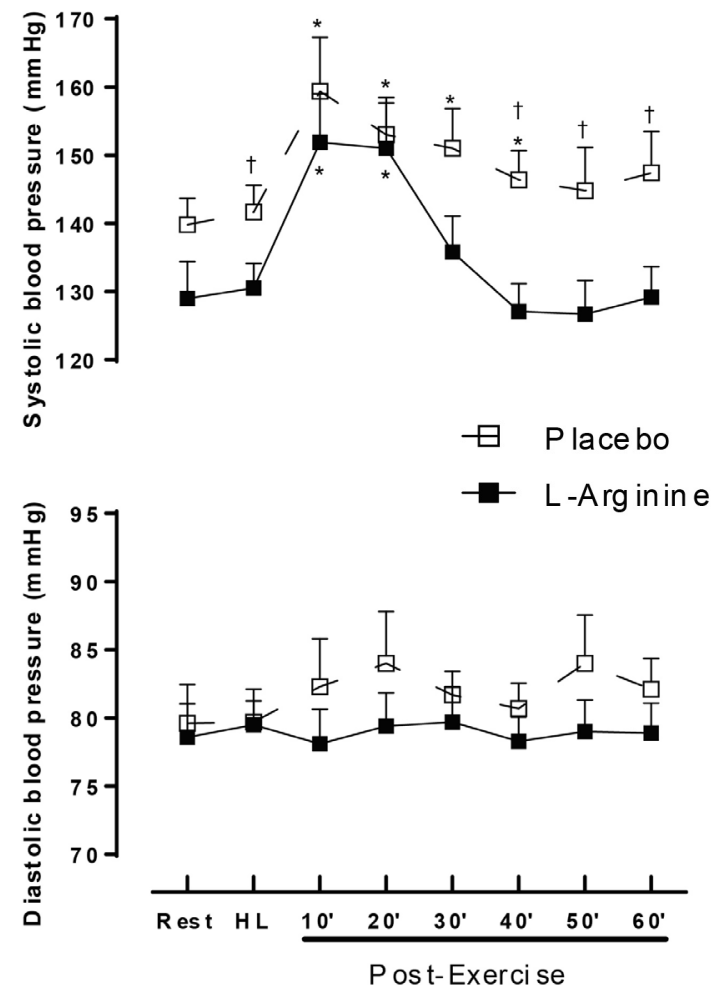

$\mathrm{HL}=$ half-life; ${ }^{*} \mathrm{P}<0.05$ vs rest; $+\mathrm{P}<0.05$ vs $\mathrm{L}$-arginine group.

Figure 1. Systolic and diastolic blood pressure changes.

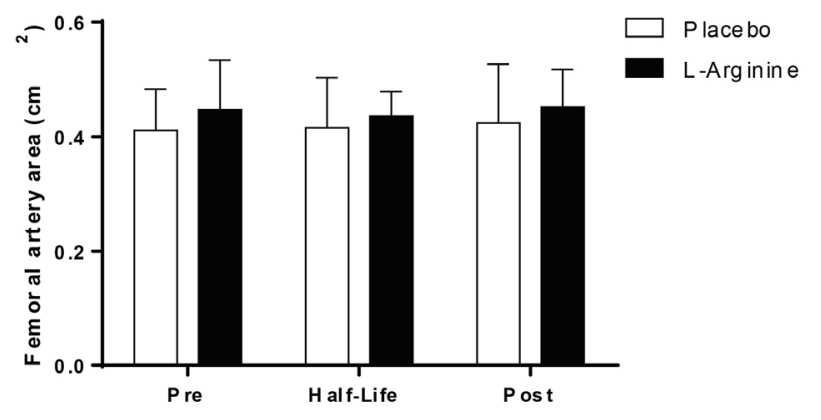

Figure 2. Femoral artery area on "pre", "half-life", and post.

management since previous studies have shown that PEH magnitude is correlated with chronic BP reductions ${ }^{19}$.

It is important to consider that ARG is the main amino acid related to the $\mathrm{NO}$ synthesis ${ }^{11}$, consequently, ARG supplementation may play an important vasodilatory role, although arginine is directly involved in protein synthesis, ureagenesis, agmatine, creatine, polyamines, and proline productions ${ }^{20}$. Data from experimental studies suggest that after oral administration, ARG is extensively metabolized by arginase in the intestine and liver, limiting their bioavailability as a NOS substrate and subsequent vasodilator function effects ${ }^{21}$.

Boger et al. ${ }^{22}$ conducted an experimental study using a stable ARG isotope labeled and were able to show that only about $1 \%$ of the ARG dose was being used as a nitric oxide synthase (NOS) substrate.

Thus, a high amino acid (8g) supplementation dose is justified in the experimental protocol, trying to ensure that even a small part of the supplement is used as a NOS substrate. This ARG dose has been previously used to promote vasodilator effect in elderly subjects ${ }^{23}$. According to Böger ${ }^{24}$, single doses of 3 to $8 \mathrm{~g}$ of ARG appear to be safe and rarely cause adverse events. On the other hand, single doses greater than $9 \mathrm{~g}$ appear to be associated with gastrointestinal discomfort and nausea ${ }^{25}$.
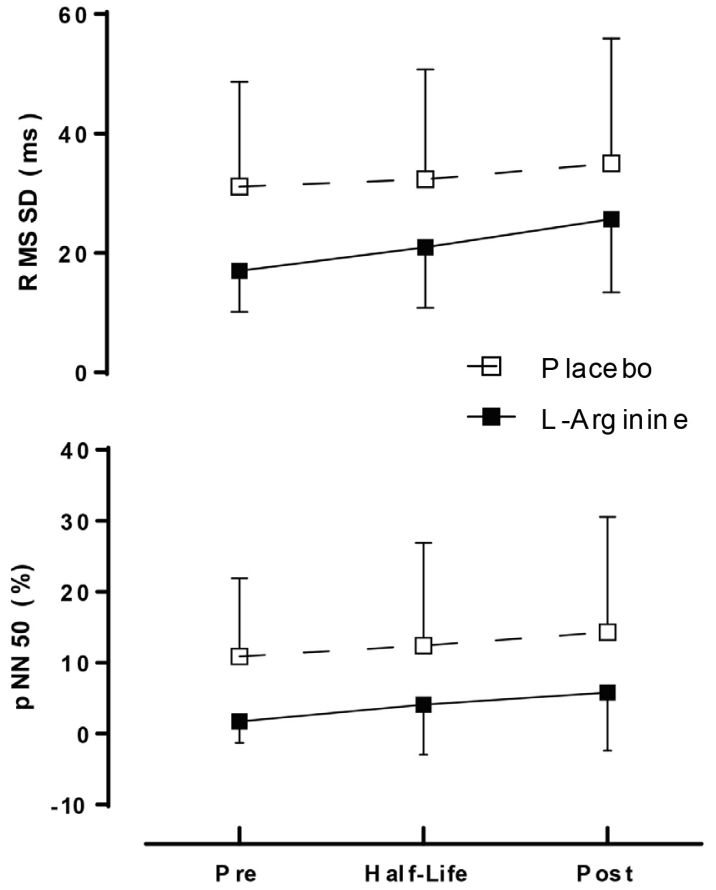

Figure 3. Time domains heart rate variability indicators.
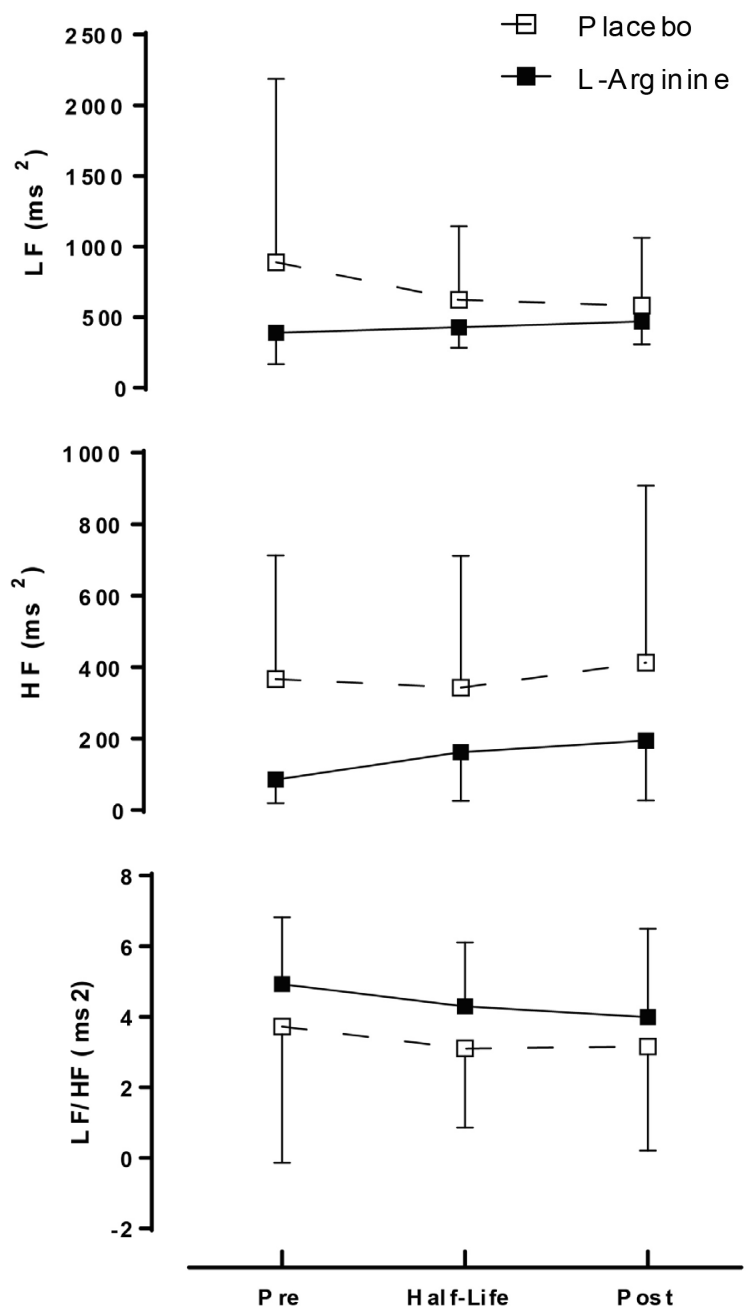

Figure 4. Frequency domains heart rate variability indicators. 
The hypothesis of the present study was that ARG supplementation would maximize the PEH, characterized by the acute BP reduction after a single physical exercise or physical activity session ${ }^{26}$. In turn, the results demonstrated that systolic BP remained lower post 40 min in the ARG supplemented group compared to placebo. This result agree with the initial hypothesis since the ARG supplementation can increase the NO production ${ }^{27}$ and consequently peripheral vasodilation ${ }^{28}$.

On the other hand, no significant effects on diastolic BP were identified in the present investigation. Studies investigating PEH has shown smaller diastolic BP variations, several investigations demonstrate $\mathrm{PEH}$ only for systolic BP in hypertensive patients ${ }^{29}$.

Another variable analyzed in the present investigation was the femoral artery area. Considering that ARG is directly associated with NO synthesis, we expected the occurrence of vasodilation. However, this increase in the femoral artery area was not confirmed, contradicting the initial hypothesis.

On the other hand, the vasodilation in large arteries may not occur systematically, since ARG supplementation may increase blood perfusion (reducing pressure) due to blood flow increase in arterioles and capillaries ${ }^{7}$. The role of microcirculation on systemic vascular resistance is about $70 \%$ of the pressure gradient between arteries and veins. The large arteries have architecture adapted to the shock absorption and blood volume accommodation every systole since the capillaries arranged in a single layer of endothelial cells lining the basement membrane cannot receive blood at systemic pressures at the risk of losing structural integrity. The required mechanical damping of the pulse wave is promoted by arterioles equipped with one or two layers of smooth muscle cells in continuous tone ${ }^{30}$. This fact suggests that arterioles were more affected by NO than great vessels.

To identify some effect related to the neuro-autonomic mechanism, HRV was investigated in different time/frequency domain components. In this sense, there was no difference in any of the evaluated components, suggesting that PEH identified is not strongly associated with the central adjustments. Since HRV is an indirect autonomic nervous system measure ${ }^{15}$, it was expected no significant changes in the HRV components, considering that HPE mechanisms were more strongly associated with the peripheral adjustments.

It is recommended that future studies add bioavailability markers of nitric oxide measurements, such as nitrite and nitrate. Additionally, evaluation of other important mechanisms such as peripheral vascular resistance and cardiac output may help in understand the ARG body action. Finally, future research about ARG supplementation impact on PEH should be performed manipulating different exercise conditions, since exercise variables can change PEH. ${ }^{4,5}$.

\section{CONCLUSION}

ARG supplementation may contribute to BP reduction after a single exercise session in hypertensive patients. In addition, ARG supplementation does not appear to promote femoral artery vasodilation and autonomic nervous system changes.

All authors declare no potential conflict of interest related to this article

AUTHORS' CONTRIBUTIONS: Each author made significant individual contributions to this manuscript. JC (0000-0001-5397-5694)*: design, writing of the article, data interpretation, and review; DMZ (0000-0003-3444-4323)*: writing, critical review, and intellectual concept; DME (0000-0001-5382-8360)*: writing and critical review; KG (0000-0002-8286-6072)*: writing and critical review; AFA (0000-0003-3337-2444)* design and critical review. ${ }^{*}$ ORCID (Open Researcher and Contributor ID).

\section{REFERÊNCIAS}

1. Campolina AG, Adami F, Santos JL, Lebrao ML. [The health transition and changes in healthy life expectancy in the elderly population: possible impacts of chronic disease prevention]. Cadernos de saude publica. 2013;29(6):1217-29.

2. Vidigal Fde C, Ribeiro AQ, Babio N, Salas-Salvado J, Bressan J. Prevalence of metabolic syndrome and pre-metabolic syndrome in health professionals: LATINMETS Brazil study. Diabetology \& metabolic syndrome. 2015;7:6.

3. Cornelissen VA, Smart NA. Exercise training for blood pressure: a systematic review and meta-analysis. J Am Heart Assoc. 2013;2(1):e004473.

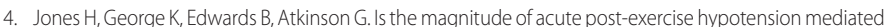
by exercise intensity or total work done? Eur J Appl Physiol. 2007;102(1):33-40.

5. Pescatello LS, Guidry MA, Blanchard BE, Kerr A, Taylor AL, Johnson AN, et al. Exercise intensity alters postexercise hypotension. J Hypertens. 2004;22(10):1881-8.

6. Vanderlei LCM, Pastre CM, Hoshi HA, Carvalho TD, Godoy MF. Noções básicas de variablidade da frequência cardíaca e sua aplicabilidade clínica. Rev Bras Cir Cardiovasc. 2009;24(2):205-17.

7. Alvares TS, Conte-Junior CA, Silva JT, Paschoalin VM. Acute L-Arginine supplementation does not increase nitric oxide production in healthy subjects. Nutrition \& metabolism. 2012;9(1):54

8. Sindler AL, Fleenor BS, Calvert JW, Marshall KD, Zigler ML, Lefer DJ, et al. Nitrite supplementation reverses vascular endothelial dysfunction and large elastic artery stiffness with aging. Aging cell. 2011;10(3):429-37.

9. Quyyumi AA, Dakak N, Andrews NP, Husain S, Arora S, Gilligan DM, et al. Nitric oxide activity in the human coronary circulation. Impact of risk factors for coronary atherosclerosis. The Journal of clinical investigation. 1995;95(4):1747-55

10. Petroczi A, Naughton DP. Potentially fatal new trend in performance enhancement: a cautionary note on nitrite. Journal of the International Society of Sports Nutrition. 2010;7:25.

11. Cynober L, Boucher JL, Vasson MP. Arginine metabolism in mammals. J Nutr Biochemistry. 1995;6(8):402-13.

12. Coleman A, Freeman P, Steel S, Shennan A. Validation of the Omron MX3 Plus oscillometric blood pressure monitoring device according to the European Society of Hypertension international protocol. Blood Press Monit. 2005;10(3):165-8

13. Pickering TG, Hall JE, Appel $\sqcup$, Falkner BE, Graves J, Hill MN, et al. Recommendations for blood pressure measurement in humans and experimental animals: part 1: blood pressure measurement in humans: a statement for professionals from the Subcommittee of Professional and Public Education of the American Heart Association Council on High Blood Pressure Research. Circulation. 2005;111(5):697-716.

14. Quintana DS, Heathers JA, Kemp AH. On the validity of using the Polar RS800 heart rate monitor for heart rate variability research. Eur J Appl Physiol. 2012;112(12):4179-80.

15. Heart rate variability: standards of measurement, physiological interpretation and clinical use. Task Force of the European Society of Cardiology and the North American Society of Pacing and Electrophysiology. Circulation. 1996;93(5):1043-65.
16. Griesenbeck JS, Steck MD, Huber JC, Jr., Sharkey JR, Rene AA, Brender JD. Development of estimates of dietary nitrates, nitrites, and nitrosamines for use with the Short Willet Food Frequency Questionnaire. Nutrition journal. 2009;8:16

17. Casonatto J, Tinucci T, Dourado AC, Polito M. Cardiovascular and autonomic responses after exercise sessions with different intensities and durations. Clinics. 2011;66(3):453-8.

18. Halliwill JR, Buck TM, Lacewell AN, Romero SA. Postexercise hypotension and sustained postexercise vasodilatation: what happens after we exercise? Exp Physiol. 2013;98(1):7-18.

19. Moreira SR, Cucato GG, Terra DF, Ritti-Dias RM. Acute blood pressure changes are related to chronic effects of resistance exercise in medicated hypertensives elderly women. Clin Physiol Funct Imaging. 2016;36(3):242-8.

20. Wu G, Morris SM, Jr. Arginine metabolism: nitric oxide and beyond. The Biochemical journal. 1998;336 (Pt 1):1-17.

21. Morris SM, Jr. Enzymes of arginine metabolism. J Nutr. 2004;134(10 Suppl):2743S-75; discussion 65S-67S.

22. Boger RH, Tsikas D, Bode-Boger SM, Phivthong-Ngam L, Schwedhelm E, Frolich JC. Hypercholesterolemia impairs basal nitric oxide synthase turnover rate: a study investigating the conversion of L-[guanidino-(15) $\mathrm{N}(2)$ ]-arginine to (15)N-labeled nitrate by gas chromatography--mass spectrometry. Nitric oxide : biology and chemistry. 2004;11(1):1-8.

23. Bode-Boger SM, Muke J, Surdacki A, Brabant G, Boger RH, Frolich JC. Oral L-arginine improves endothelial function in healthy individuals older than 70 years. Vascular medicine. 2003;8(2):77-81.

24. Boger RH. The pharmacodynamics of L-arginine. J Nutr. 2007;137(6 Suppl 2):1650S-5S.

25. Grimble GK. Adverse gastrointestinal effects of arginine and related amino acids. The Journal of nutrition. 2007;137(6 Suppl 2):1693S-701S

26. Pescatello LS, Franklin BA, Fagard R, Farquhar WB, Kelley GA, Ray CA, et al. American College of Sports Medicine position stand. Exercise and hypertension. Medicine and science in sports and exercise. 2004;36(3):533-53.

27. Nichols $K$, Staines W, Rubin S, Krantis A. Distribution of nitric oxide synthase activity in arterioles and venules of rat and human intestine. The American journal of physiology. 1994;267(2 Pt 1):G270-5.

28. Tang JE, Lysecki PJ, Manolakos JJ, MacDonald MJ, Tarnopolsky MA, Phillips SM. Bolus arginine supplementation affects neither muscle blood flow nor muscle protein synthesis in young men at rest or after resistance exercise. The Journal of nutrition. 2011;141(2):195-200.

29. Costa JBY, Gerage AM, Gonçalves CGS, Pina FLC, Polito MD. Influence of the training status on the blood pressure behavior after a resistance training session in hypertensive older females. Rev Bras Med Esporte. 2010;16(2):103-6.

30. Kaiser SE. Contribuição do estudo da microcirculação à fisiopatologia da hipertensão arterial. Revista HUPE. 2011;10(3):31-8 